\title{
Effect of diet on human adipose tissue metabolism
}

\author{
BY KEITH N. FRAYN, SIMON W. COPPACK \\ AND JENNIFER L. POTTS \\ Oxford Lipid Metabolism Group, The Sheikh Rashid Laboratory, Radcliffe Infirmary, \\ Oxford $O X 26 H E$
}

Adipose tissue is, in one sense, the tissue most affected by diet. As the ultimate reservoir for energy storage, its mass reflects an integration of energy imbalance during the bearer's life. Diet also has qualitative effects on adipose tissue: for instance, the pattern of adipose tissue triacylglycerol (TAG)-fatty acids reflects the dietary fatty acid pattern (Hirsch, 1965; Jacobsen et al. 1983; van Staveren et al. 1986), and fat-soluble xenobiotics (such as pesticides) accumulate in adipose tissue fat (Handelman et al. 1988). Only the energy storage aspect will be considered here.

Long-term changes in body-weight involve a change in the amount of TAG stored in adipose tissue; there is a very strong relationship between the body-weight and the body fat content (both corrected for height; Webster et al. 1984). (The associated changes in non-fat tissue will not be considered here.) The processes of fat deposition and fat mobilization are, therefore, in a metabolic sense, the final common pathways for procedures influencing body-weight. The general principle of energy balance, that energy consumed equals energy expended plus the change in body energy stores, cannot be contradicted. But the link between a change in body energy stores and a change in the amount of fat (TAG) stored in adipose tissue is not so obvious. Our studies over the past few years have been aimed at elucidating some of the regulatory aspects of fat deposition and mobilization in humans, and attempting to relate these to energy balance.

\section{ROUTES OF FAT MOBILIZATION AND DEPOSITION}

There are, in principle, two routes by which fat may be deposited in the form of adipose tissue TAG: uptake of preformed fatty acids, and uptake of other substrates which can be converted to TAG. In practice, the former means fatty acids derived from circulating TAG, either chylomicron-TAG or very-low-density lipoprotein (VLDL)-TAG. Adipocytes will take up labelled extracellular non-esterified fatty acids (NEFA) (Abumrad et al. 1984; Sorrentino et al. 1989), but the mass gradient of NEFA in vivo is always in the direction of NEFA release (Coppack et al. 1990a,b). Circulating TAG is hydrolysed by lipoprotein lipase (LPL; EC 3.1.1.34) situated in the capillary lumen. The action and regulation of this enzyme have been thoroughly reviewed recently (Eckel, 1987, 1989; Williamson, 1990). In brief, it is synthesized within adipocytes, modified intracellularly, and exported to its site of action (bound to the endothelium via heparan sulphate chains). Its synthesis, activation and possibly transport to the endothelium are all stimulated by insulin, the whole process of stimulation taking a matter of hours (Sadur \& Eckel, 1982). The fate of the fatty acids released by LPL action is not entirely clear. At least a proportion will reach the adipocytes, where they may be taken up for esterification and storage; various models for the 'microanatomy' of adipose tissue which allow them to make this journey have been reviewed recently (Frayn, 1992). Some 


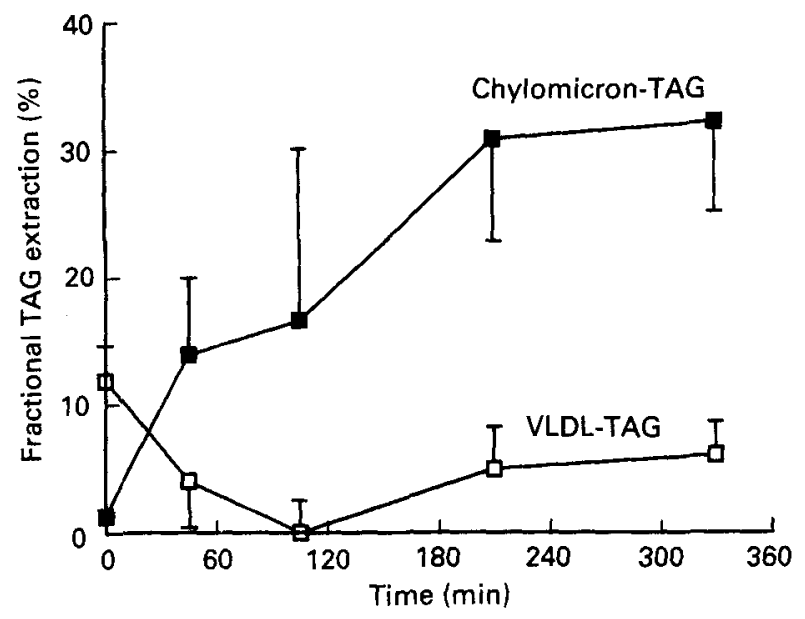

Fig. 1. Fractional extraction of triacylglycerol (TAG) during passage through human subcutaneous adipose tissue for nine normal subjects. Values at time 0 are each means of three measurements after an overnight fast. Between 0 and 20 min a mixed meal (composition given on p. 415) was eaten. (囵, Chylomicron-TAG; ( $\square$ ), very-low-density lipoprotein (VLDL)-TAG. Reproduced from Potts et al. (1991a) with permission of Portland Press.

fatty acids released by LPL will, however, 'escape' into the venous plasma. This escape is particularly prominent in the postprandial phase when there is a high rate of hydrolysis of chylomicron-TAG (Coppack et al. 1990a). It is still not clear (in teleological terms) whether this represents simple 'inefficiency' or whether the body gains by such a tactic, for instance by directing fatty acids from dietary fat to other tissues for possible oxidation or storage. LPL has certain substrate preferences. It is specific for the 1- and 3- linkages in acylglycerols (Nilsson-Ehle et al. 1973) and its action thus leaves a 2-monoacylglycerol (MAG). This has to isomerize to a 1(3)-MAG before hydrolysis, and MAG will accumulate during rapid hydrolysis in vitro (Scow \& Olivecrona, 1977). The possibility of MAG uptake by adipocytes (as in enterocytes) has occasionally been suggested (Small, 1991) but not, so far as we are aware, tested. It would presumably be followed by hydrolysis since adipose tissue contains a very active MAG lipase, whereas the MAG esterification pathway (active in enterocytes) is not thought to be important in adipose tissue. LPL also has preferences amongst the TAG-rich lipoproteins. Chylomicrons are much better substrates than VLDL, to the extent that they compete for hydrolysis postprandially, causing a rise in the plasma VLDL-TAG concentration (Potts et al. $1991 a, b$; Fig. 1).

The other possible route of fat deposition, via de novo lipogenesis, has attracted much experimental attention, especially in the rat. In experimental animals on highcarbohydrate, low-fat diets it may well be important, although even in the rat a large proportion of adipose tissue TAG arises from uptake of preformed fatty acids (Williamson, 1990). In humans, there is little evidence for de novo lipogenesis during normal life as a route of net fat deposition (Acheson et al. 1982), and some doubt about the enzyme capacity for carrying it out, at least in adipose tissue (Shrago et al. 1969). The correspondence, discussed earlier, between fatty acid patterns in adipose tissue TAG 
and diet also points towards direct uptake of dietary fat as the most important route of adipose tissue TAG deposition under normal conditions.

The process of fat mobilization (liberation of NEFA from adipose tissue for use as a substrate in other tissues) has been well reviewed by others (Fain, 1980; Belfrage, 1985; Vernon \& Clegg, 1985). The stored TAG is hydrolysed by the so-called hormonesensitive lipase (HSL; EC 3.1.1.3). This interesting enzyme has been very difficult to study in detail since it is largely hydrophobic and difficult to solubilize. Its gene has recently been cloned (Holm et al. 1988), however, and its cellular and molecular biology are now being unravelled. Removal of the first fatty acid by HSL is the rate-limiting step in lipolysis; HSL also removes the second fatty acid, and the third is removed by an active MAG lipase (EC 3.1.1.23). The products are, thus, glycerol and NEFA. Glycerol does not appear to be utilized to a significant extent in adipose tissue (Lin, 1977) and is largely exported, whereas the fatty acids may be re-esterified after activation by condensation with acetyl-CoA. The activity of HSL is regulated on a rapid basis by phosphorylation-dephosphorylation, the former stimulated (via cyclic-AMP) by glucagon and $\beta$-adrenergic agents. Dephosphorylation is brought about by insulin (at least in part by activation of a phosphodiesterase activity and reduction of cyclic-AMP levels (Belfrage, 1985)) and by agents inhibiting adenylate cyclase ( $E C$ 4.6.1.1) via $\mathrm{G}_{\mathrm{i}}$ proteins (e.g. adenosine, prostaglandin $E_{2}$, nicotinic acid and analogues). Control of HSL activity via these mechanisms appears to be the major short-term regulatory mechanism for lipolysis. Release of NEFA, on the other hand, is controlled also by the rate of re-esterification. Thus, insulin reduces lipolysis and also increases the proportion of fatty acids re-esterified and, thus, retained in the tissue (Fig. 2), presumably via increased provision of glycerol-3-phosphate. In terms of diet and adipose tissue metabolism, the role of insulin in regulating NEFA release is probably paramount. In the postprandial period, with a high insulin concentration, fatty acids are retained within the adipocyte both by reduced HSL activity and by increased re-esterification (Coppack et al. 1992). As the postprandial phase leads into the post-absorptive phase and insulin levels fall, fatty acid release returns (Coppack et al. 1990a).

\section{EXPERIMENTAL APPROACHES}

In an attempt to provide more direct information about the processes of fat deposition and mobilization in human adipose tissue, we developed a few years ago a technique for measurement of arterio-venous concentration differences across a subcutaneous adipose depot, that of the anterior abdominal wall (Frayn et al. 1988, 1989). This site has some unique features: it has a reasonably well-defined system of venous drainage, accessible for cannulation (albeit with difficulty), and its vasculature is completely separated from that of the underlying muscle bed by an avascular fibrous sheath, the aponeurosis of the external oblique muscle. Blood sampled from the major veins draining this depot, the superficial circumflex iliac and the superficial epigastric, represents drainage from adipose tissue with a contribution (which we believe to be small in most subjects) from the overlying skin. We have compared this blood with that taken from a vein draining a warmed hand ('arterialized') or from a radial artery, and, in some studies, with blood taken from a deep antecubital vein draining mainly forearm muscle. In our later studies, adipose tissue blood flow was measured using the ${ }^{133} \mathrm{Xe}$ clearance technique (Larsen et al. 1966). 

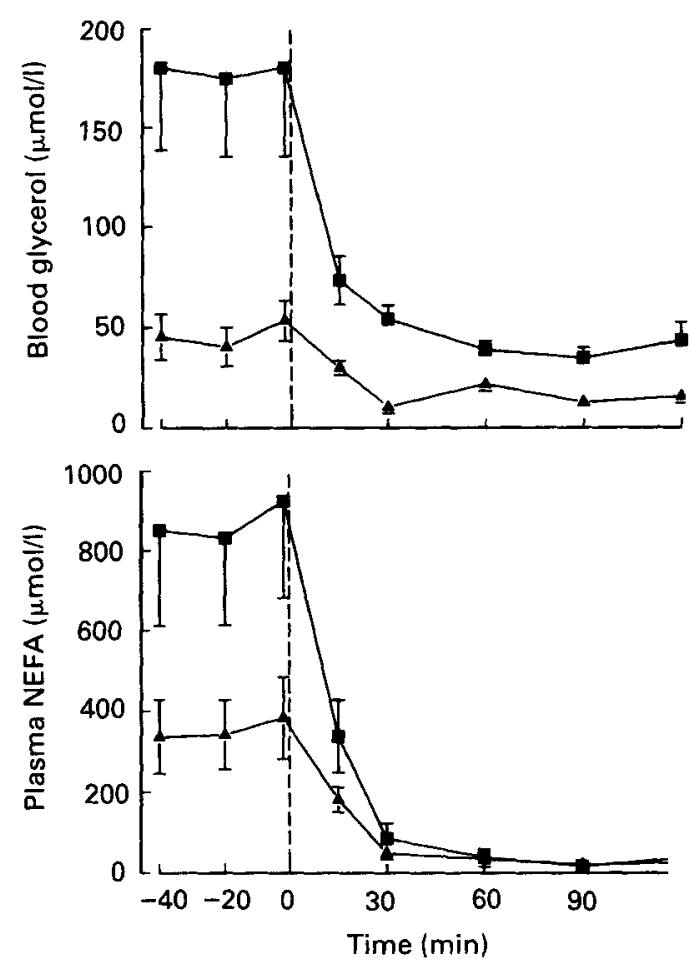

Fig. 2. Plasma non-esterified fatty acid (NEFA) and blood glycerol concentrations for eight normal subjects, after overnight fast ( -40 to $0 \mathrm{~min}$ ) and then during infusion of insulin at $35 \mathrm{mU} / \mathrm{m}^{2}$ per min, with the plasma glucose concentration 'clamped' at $5 \mathrm{mmol} / \mathrm{l}$. ( $\boldsymbol{\Delta})$, Arterialized blood; ( $\mathbf{\square})$, venous drainage from subcutaneous adipose tissue. The difference between arterialized and venous thus represents the release from adipose tissue, which is completely suppressed by insulin in the case of NEFA, less so in the case of glycerol. Based on data in Coppack et al. (1989), and reproduced from Frayn (1992) with permission of Raven Press Ltd.

Human adipose tissue in vivo does not have the simple metabolic pattern that might be expected from studies of adipocytes in vitro. Even in the post-absorptive state (taken here to mean after an overnight fast), it is engaged in a variety of metabolic exchanges. TAG, glucose, oxygen, acetoacetate and 3-hydroxybutyrate and acetate are all extracted from the blood, and NEFA, glycerol, lactate and carbon dioxide are released. (Pyruvate exchange is variable and not significant in either direction amongst a group of subjects.) Also amino acid metabolism is not negligible, although it will not be considered in detail in the present review; the tissue releases both alanine and glutamine, and takes up glutamate, at rates that may give it an appreciable role in the whole body (Frayn et al. 1991). In terms of overall balance of substrates (assessed by the 'carbon atom balance' in all these substrates), adipose tissue is a considerable exporter of substrate carbon in the post-absorptive state. The forearm, in contrast, whilst engaged in exchange of many of the same substrates, takes up rather than releases NEFA, and thereby remains nearly in 'carbon balance' after overnight fast (Fig. 3).

The export of material in the post-absorptive state must be balanced (if body-weight is relatively steady) by import of carbon-containing substrates in the fed state. From the 


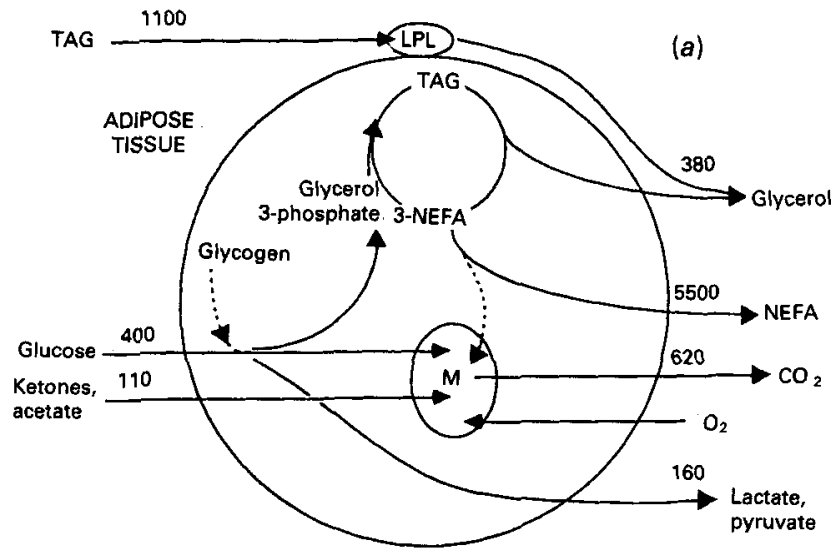

Total in: $1610 \quad$ Total out: 6660

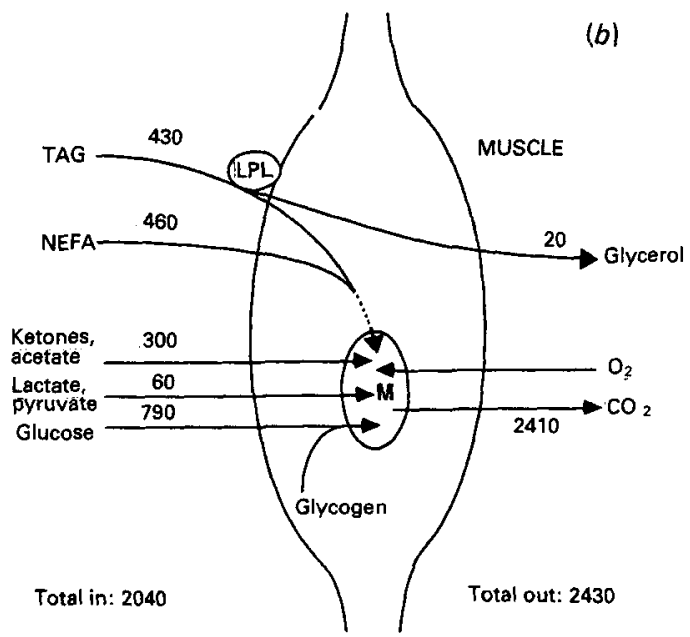

Fig. 3. Carbon atom balances ( $\mu$ g atoms/l whole blood) across ( $a$ ) subcutaneous adipose tissue and $(b)$ forearm muscle after overnight fast. Results are mean values from twenty-five studies of normal subjects. LPL, lipoprotein lipase (EC 3.1.1.34); M, mitochondrion; NEFA, non-esterified fatty acids; TAG, triacylglycerol. Reproduced from Coppack et al. (1990b) with permission of W. B. Saunders Co.

description of fat deposition given previously, it is to be expected that the main sources will be TAG and (to a lesser extent) glucose. We investigated the change in adipose tissue substrate balance produced by giving an oral glucose load ( $75 \mathrm{~g}$ glucose monohydrate, $1160 \mathrm{~kJ}$ ). Much as expected (Fig. 4(b)), after the glucose there was a change to net carbon uptake in both adipose tissue and forearm (more pronounced and more sustained in the latter). It can then be asked: what was the major change in substrate exchange bringing about this switch from carbon export to import? The biggest single change was not a positive uptake of any one substrate, but a suppression of the 

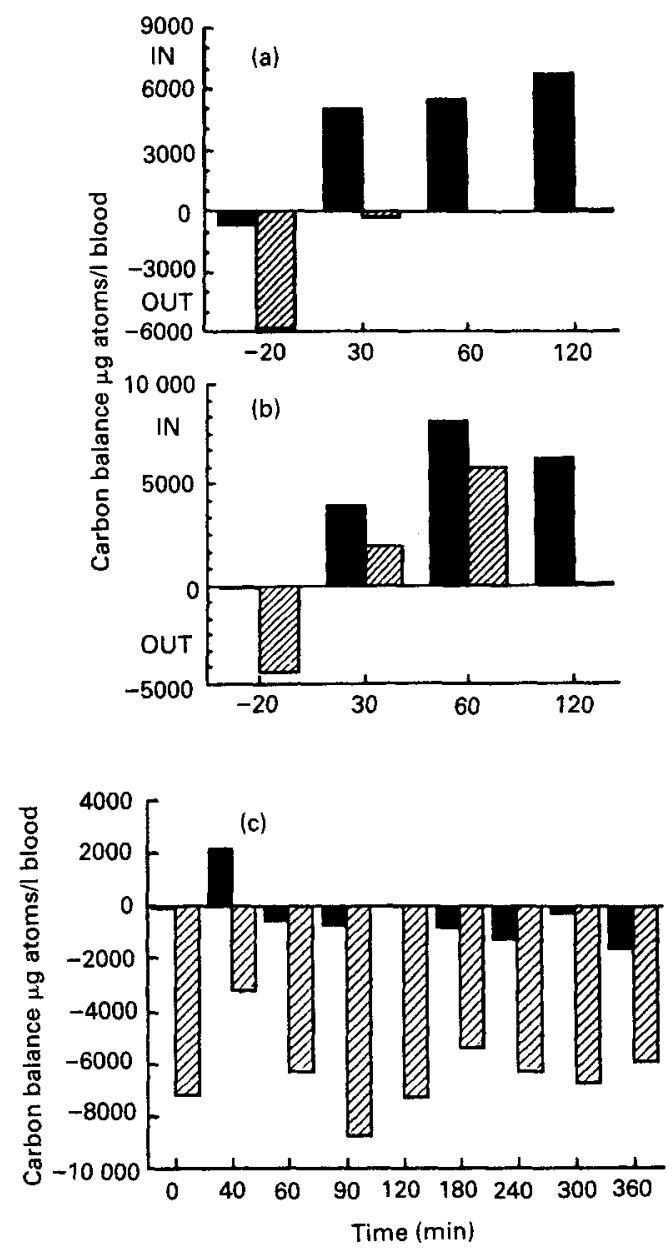

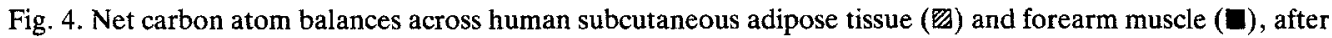
overnight fast $(-20$ or 0$)$ and then: (a) during infusion of insulin (see Fig. 2); (b) after ingestion of $75 \mathrm{~g}$ glucose monohydrate; $(c)$, after ingestion of $47.5 \mathrm{~g}$ ethanol. Positive values represent net uptake of carbon atoms by the tissue, negative values represent net export. Based on data in Coppack et al. (1989) and Frayn et al. (1990b); reproduced from Frayn (1992) with permission of Raven Press Ltd.

release of NEFA. Thus, net nutrient uptake into adipose tissue after a glucose load is brought about mainly by suppression of fat mobilization (Frayn et al. 1990a).

The role of insulin in bringing about this change was investigated by infusing insulin, using a euglycaemic ( $5 \mathrm{mmol} / \mathrm{l}$ ) clamp procedure (Coppack et al. 1989). Insulin was infused for $2 \mathrm{~h}$ at $35 \mathrm{mU} / \mathrm{m}^{2}$ per min, producing plasma insulin concentrations of about $50 \mathrm{mU} / \mathrm{l}$, similar to the peak reached after oral glucose. The effect on net substrate storage in adipose tissue was much less pronounced than that of glucose ingestion (Fig. $4(a)$ ), although the effect in the forearm was very similar. In terms of individual substrate exchanges, insulin infusion completely suppressed NEFA release from adipose tissue (see Fig. 2), but produced only a slight stimulation of glucose uptake. 
Ethanol is another energy-providing substrate, at least in so far as energy is released when it is burnt in a bomb calorimeter $(\Delta \mathrm{H}=-30 \mathrm{~kJ} / \mathrm{g})$. There are some features of ethanol ingestion which are not, however, clear. Some dietary studies show that increased ethanol consumption is not accompanied by the expected change in bodyweight (Pirola \& Lieber, 1972; Colditz et al. 1991). Pathways have been suggested by which ethanol may be oxidized without generation of useful energy, via a microsomal oxidation system with concomitant peroxisomal oxidation of NADPH (Pirola \& Lieber, 1972, 1976) or via futile cycling between ethanol and acetaldehyde (Lands \& Zakhari, 1991). On the other hand, in experiments designed to look at the 'thermic effect' of ethanol consumption, no evidence for excessive thermogenesis was found (Shelmet et al. 1988; Reinus et al. 1989). From a biochemical point of view, ethanol illustrates very clearly the difficulty of linking the 'energy value' of a nutrient (as assessed in a bomb calorimeter) with the (net) storage of TAG in adipose tissue. Ethanol is metabolized via acetaldehyde to acetate in the liver. Clearly the NAD(P)H or ATP thus generated cannot be transferred directly to adipose tissue; and yet, it would seem that there must be a mechanism which results in the net retention of fatty acids within adipose tissue, corresponding on a 'joule for joule' basis to hepatic ethanol oxidation. What could be the nature of such a link? Acetate may have an anti-lipolytic effect (Crouse et al. 1968); but, if this is the explanation, it would seem to be 'fortuitous' rather than a necessary consequence of hepatic oxidation of an energy-bearing substrate. In any case, the evidence for acetate and anti-lipolysis is not strong, and there is no evidence in vivo for increased acetate uptake by adipose tissue after ethanol ingestion (Frayn et al. 1990b). Other acute studies have suggested that ethanol ingestion spares carbohydrate rather than fat oxidation (Sonko et al. 1991). In an attempt to investigate the link between ethanol and adipose tissue fat stores, normal subjects were given $47.5 \mathrm{~g}$ ethanol (in the form of gin and low-energy tonic) after overnight fast: this is a rather larger energy load than the $75 \mathrm{~g}$ glucose monohydrate used in our earlier studies $(1400 \mathrm{~kJ} v .1160 \mathrm{~kJ})$. The 'carbon balance' was followed across the adipose tissue for $6 \mathrm{~h}$ after ethanol ingestion. There was no tendency for 'net substrate storage' in the tissue as there had been after glucose ingestion (Fig. 4(c)). These experiments cannot rule out a steady, slow sparing of NEFA release from adipose tissue, but if this occurred, the mechanism by which it was brought about was not obvious. Clearly, the effects of 'ethanol energy' on adipose tissue metabolism are qualitatively very different from the effects of 'glucose energy'.

At a more complex level, the responses to ingestion of a 'real meal' (chicken, vegetables, biscuits, fruit and ice cream) containing $3 \cdot 1 \mathrm{MJ}$, of which $41 \%$ were from fat and $47 \%$ from carbohydrate (Coppack et al. 1990a, 1992), were studied. The comparison of forearm muscle and adipose tissue in these studies was very revealing. Both tissues changed to net carbon intake after the meal. In the forearm, this was brought about almost entirely by increased glucose uptake (the time-course of which mirrored very closely the plasma insulin concentration). In adipose tissue, uptake of fat was predominant. (The avid extraction of chylomicron-TAG shown in Fig. 1, based on the same experiments, reflects this.) The carbon balance across adipose tissue depended largely on the interplay between NEFA release and TAG uptake (Fig. 5). These studies emphasize the metabolic 'ease' with which dietary fat is taken up for storage in adipose tissue, but again highlight the subtle regulation of net fat storage by regulation of both fat uptake and fatty acid release. 


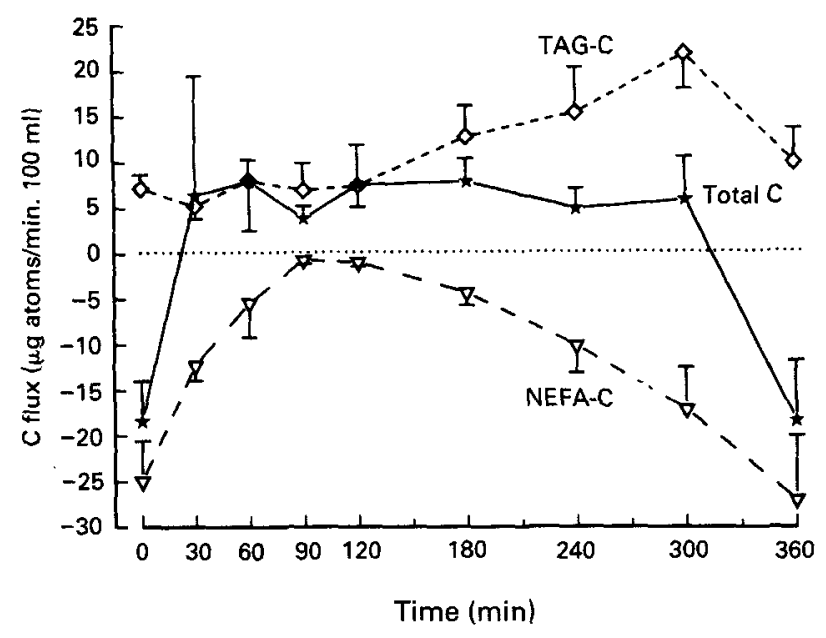

Fig. 5. Net carbon atom fluxes (arterio-venous difference $\times$ blood flow) across human subcutaneous adipose tissue after overnight fast (time 0 ) and after ingestion of a mixed meal (see Fig. 1). ( $\star$ ), Total $\mathrm{C}$ flux (sum of $\mathrm{C}$ atoms in eight major substrates); $(\diamond), \mathrm{C}$ atom import from plasma $\mathrm{TAG} ;(\nabla), \mathrm{C}$ atom export as NEFA. Reproduced from Coppack et al. (1990a) with permission of Portland Press.

\section{CONCLUSION}

There is a challenge facing those interested in the interactions between diet, metabolism and adiposity. At a whole-body level, the relationship between energy intake, energy expenditure and energy storage is clear (indeed, incontrovertible). The translation of this energy storage into a change in body fat stores, on a joule for joule basis, is not clear. There is much to be learned about the precise quantitative regulation of intermediary metabolism, and adipose tissue is a tissue in which we, as nutritionists, should have a special interest.

The authors thank their many colleagues who contributed to these studies, and Dr. T. D. R. Hockaday for stimulating discussions. The Sheikh Rashid Diabetes Unit is funded by the Oxford Diabetes Trust. The studies were supported in part by the British Heart Foundation, the Humane Research Trust and the Oxford Regional Health Authority. S.W.C. held an MRC Training Fellowship and J.L.P. a Glaxo Group Research Studentship.

\section{REFERENCES}

Abumrad, N. A., Park, J. H. \& Park, C. R. (1984). Permeation of long-chain fatty acid into adipocytes. Kinetics, specificity, and evidence for involvement of a membrane protein. Journal of Biological Chemistry 259, 8945-8953.

Acheson, K. J., Flatt, J. P. \& Jéquier, E. (1982). Glycogen synthesis versus lipogenesis after a 500 gram carbohydrate meal in man. Metabolism 31, 1234-1240.

Belfrage, P. (1985). Hormonal control of lipid degradation. In New Perspectives in Adipose Tissue, pp. 121-144 [A. Cryer and R. L. R. Van, editors]. London: Butterworths.

Colditz, G. A., Giovannuci, E., Rimm, E. B., Stampfer, M. J., Rosner, B., Speizer, F. E., Gordis, E. \& Willett, W. C. (1991). Alcohol intake in relation to diet and obesity in women and men. American Journal of Clinical Nutrition 54, 49-55. 
Coppack, S. W., Evans, R. D., Fisher, R. M., Frayn, K. N., Gibbons, G. F., Humphreys, S. M., Kirk, M. J., Potts, J. L. \& Hockaday, T. D. R. (1992). Adipose tissue metabolism in obesity; lipase action in vivo before and after a mixed meal. Metabolism 41, 264-272.

Coppack, S. W., Fisher, R. M., Gibbons, G. F., Humphreys, S. M., McDonough, M. J., Potts, J. L. \& Frayn, K. N. (1990a). Postprandial substrate deposition in human forearm and adipose tissues in vivo. Clinical Science 79, 339-348.

Coppack, S. W., Frayn, K. N., Humphreys, S. M., Dhar, H. \& Hockaday, T. D. R. (1989). Effects of insulin on human adipose tissue metabolism in vivo. Clinical Science 77, 663-670.

Coppack, S. W., Frayn, K. N., Humphreys, S. M., Whyte, P. L. \& Hockaday, T. D. R. (1990b). Arteriovenous differences across human adipose and forearm tissues after overnight fast. Metabolism 39, 384-390.

Crouse, J. R., Gerson, C. D., DeCarli, L. M. \& Lieber, C. S. (1968). Role of acetate in the reduction of plasma free fatty acids produced by ethanol in man. Journal of Lipid Research 9, 509-512.

Eckel, R. H. (1987). Adipose tissue lipoprotein lipase. In Lipoprotein Lipase, pp. 79-132 [J. Borensztajn, editor]. Chicago: Evener.

Eckel, R. H. (1989). Lipoprotein lipase. A multifunctional enzyme relevant to common metabolic diseases. New England Journal of Medicine 320, 1060-1068.

Fain, J. N. (1980). Hormonal regulation of lipid mobilization from adipose tissue. In Biochemical Actions of Hormones, pp. 119-204 [G. Litwack, editor]. New York: Academic Press.

Frayn, K. N. (1992). Studies of human adipose tissue in vivo. In Energy Metabolism: Tissue Determinants and Cellular Corollaries, pp. 267-295 [J. M. Kinney and H. N. Tucker, editors]. New York: Raven Press.

Frayn, K. N., Coppack, S. W. \& Humphreys, S. M. (1990a). Net substrate deposition in human adipose tissue in vivo after glucose ingestion and during insulin infusion. Proceedings of the Nutrition Society 49, $21 \mathrm{~A}$.

Frayn, K. N., Coppack, S. W., Humphreys, S. M. \& Whyte, P. L. (1989). Metabolic characteristics of human adipose tissue in vivo. Clinical Science 76, 509-516.

Frayn, K. N., Coppack, S. W., Walsh, P. E., Butterworth, H. C., Humphreys, S. M. \& Pedrosa, H. C. $(1990 b)$. Metabolic responses of forearm and adipose tissues to acute ethanol ingestion. Metabolism 39, $958-966$.

Frayn, K. N., Coppack, S. W., Whyte, P. L., Humphreys, S. M. \& Ng, L. L. (1988). Measurement of arteriovenous differences across an adipose depot in man. Proceedings of the Nutrition Society 47, 173A.

Frayn, K. N., Khan, K., Coppack, S. W. \& Elia, M. (1991). Amino acid metabolism in human subcutaneous adipose tissue in vivo. Clinical Science $80,471-474$.

Handelman, G. J., Epstein, W. L., Machlin, L. J., van Kuijk, F. J. G. M. \& Dratz, E. A. (1988). Biopsy method for human adipose tissue with vitamin $\mathrm{E}$ and lipid measurements. Lipids 23, 598-604.

Hirsch, J. (1965). Fatty acid patterns in human adipose tissue. In Handbook of Physiology. Section 5: Adipose Tissue, pp. 181-189 [A. E. Renold and G. F. Cahill, editors]. Washington, DC: American Physiological Society.

Holm, C., Kirchgessner, T. G., Svenson, K. L., Fredrikson, G., Nilsson, S., Miller, C. G., Shively, J. E., Heinzmann, C., Sparkes, R. S., Mohandas, T., Lusis, A. J., Belfrage, P. \& Schotz, M. C. (1988). Hormone-sensitive lipase: sequence, expression, and chromosomal localization to 19 cent-ql3.3. Science 241, 1503-1506.

Jacobsen, B. K., Trygg, K., Hjermann, I., Thomassen, M. S., Real, C. \& Norum, K. R. (1983). Acyl patterns of adipose tissue triglycerides, plasma fatty acids, and diet of a group of men participating in a primary coronary prevention program (The Oslo Study). American Journal of Clinical Nutrition 38, 906-913.

Lands, W. E. M. \& Zakhari, S. (1991). The case of the missing calories. American Journal of Clinical Nutrition 54, $47-48$.

Larsen, O. A., Lassen, N. A. \& Quaade, F. (1966). Blood flow through human adipose tissue determined with radioactive xenon. Acta Physiologica Scandinavica 66, 337-345.

Lin, E. C. C. (1977). Glycerol utilisation and its regulation in mammals. Annual Review of Biochemistry 46, 765-795.

Nilsson-Ehle, P., Egelrud, T., Belfrage, P., Olivecrona, T. \& Borgström, B. (1973). Positional specificity of purified milk lipoprotein lipase. Journal of Biological Chemistry 248, 6734-6737.

Pirola, R. C. \& Lieber, C. S. (1972). The energy cost of the metabolism of drugs, including ethanol. Pharmacology 7, 185-196.

Pirola, R. C. \& Lieber, C. S. (1976). Hypothesis: energy wastage in alcoholism and drug abuse: possible role of hepatic microsomal enzymes. American Journal of Clinical Nutrition 29, 90-93. 
Potts, J. L., Fisher, R. M., Humphreys, S. M., Coppack, S. W., Gibbons, G. F. \& Frayn, K. N. (1991a). Peripheral triacylglycerol extraction in the fasting and post-prandial states. Clinical Science 81, 621-625.

Potts, J. L., Fisher, R. M., Humphreys, S. M., Coppack, S. W., Gibbons, G. F. \& Frayn, K. N. (1991b). Chylomicrons are the preferred substrate for lipoprotein lipase in vivo. Biochemical Society Transactions 19, 314S.

Reinus, J. F., Heymsfield, S. B., Wiskind, R., Casper, K. \& Galambos, J. T. (1989). Ethanol: relative fuel value and metabolic effects in vivo. Metabolism 38, 125-135.

Sadur, C. N. \& Eckel, R. H. (1982). Insulin stimulation of adipose tissue lipoprotein lipase. Use of the euglycemic clamp technique. Journal of Clinical Investigation 69, 1119-1125.

Scow, R. O. \& Olivecrona, T. (1977). Effect of albumin on products formed from chylomicron triacylglycerol by lipoprotein lipase in vitro. Biochimica et Biophysica Acta 487, 472-486.

Shelmet, J. J., Reichard, G. A., Skutches, C. L., Hoeldtke, R. D., Owen, O. E. \& Boden, G. (1988). Ethanol causes acute inhibition of carbohydrate, fat, and protein oxidation and insulin resistance. Journal of Clinical Investigation 81, 1137-1145.

Shrago, E., Spennetta, T. \& Gordon, E. (1969). Fatty acid synthesis in human adipose tissue. Journal of Biological Chemistry 244, 2761-2766.

Small, D. M. (1991). The effects of glyceride structure on absorption and metabolism. Annual Review of Nutrition 11, 413-434.

Sonko, B. J., Goldberg, G. R., Murgatroyd, P. R., Coward, W. A. \& Prentice, A. M. (1991). Does consumption of alcohol with a meal promote fat storage? Proceedings of the Nutrition Society 50, 38A.

Sorrentino, D., Robinson, R. B., Kiang, C.-L. \& Berk, P. D. (1989). At physiologic albumin/oleate concentrations oleate uptake by isolated hepatocytes, cardiac myocytes, and adipocytes is a saturable function of the unbound oleate concentration. Uptake kinetics are consistent with the conventional theory. Journal of Clinical Investigation 84, 1325-1333.

van Staveren, W. A., Deurenberg, P., Katan, M. B., Burema, J., de Groot, L. C. P. G. M. \& Hoffmans, D. A. F. (1986). Validity of the fatty acid composition of subcutaneous fat tissue microbiopsies as an estimate of the long-term average fatty acid composition of the diet of separate individuals. American Journal of Epidemiology 123, 455-463.

Vernon, R. G. \& Clegg, R. A. (1985). The metabolism of white adipose tissue in vivo and in vitro. In New Perspectives in Adipose Tissue, pp. 65-86 [A. Cryer and R. L. R. Van, editors]. London: Butterworths.

Webster, J. D., Hesp, R. \& Garrow, J. S. (1984). The composition of excess weight in obese women estimated by body density, total body water and total body potassium. Human Nutrition: Clinical Nutrition 38C, 299-306.

Williamson, D. H. (1990). The endocrine control of adipose tissue metabolism and the changes associated with lactation and cancer. In The Control of Body Fat Content, pp. 43-61 [J. M. Forbes and G. R. Hervey, editors]. London: Smith-Gordon \& Co Ltd. 